\title{
Application of Bibliometric Analysis in the Research of Scientific Publications on the Quality Management of Medical Services
}

\author{
Joanna Anna Jończyk ${ }^{1}$, Anna Małgorzata Olszewska ${ }^{1}$, \\ Kamila Jończyk ${ }^{2}$ \\ 1 Faculty of Engineering Management, Bialystok University of Technology, Poland \\ 2 Student of Medical University of Bialystok, Poland
}

\begin{abstract}
The aim of the article is to present the results of bibliometric analyzes of scientific papers on the quality management of medical services published in 2001-2017 and indexed in the Scopus database. The analysis uses basic techniques of bibliometric analysis with the technical support of VOSviewer software. The publication proposes an original procedure for analyzing the literature on the subject. The results of the study allowed to determine the trends in the number of publications from 2010 to 2017. At the same time, an analysis of areas of science was presented, in which issues related to the management of the quality of medical services were analyzed, as well as citation of main authors and research centers. The whole analysis concerning the topic of quality management of medical services and bibliometric analysis of scientific works on the concepts and interrelations studied has identified the main six clusters that related to the management of quality of medical services ranging from broadly understood changes in healthcare organizations, internal quality management factors, development issues and education, regulation and standardization of the concept of quality improvement, and technological aspects of quality management in medical services. It seems, therefore, that the conducted studies can be considered as a specific guide for those interested in risk and uncertainty, despite the fact that they are not free of restrictions, for example, due to the narrowing of the time or criteria concerning the types of documents examined. In this context, the analyzes carried out give a wide range of opportunities to propose new research ideas on the above issues in contemporary organizations.
\end{abstract}

\section{Introduction}

It is difficult to disagree with the statement that in today's age quality (of services, production, or life in general) is a special challenge in every country and field. The current market conditions, increased competitiveness, rapidly changing needs and preferences of societies force healthcare 
organizations to change the way they operate and seek new strategies to build a pro-quality market advantage. It is commonly believed that an adequate level of quality of health services leads to various types of positive economic effects and, consequently, to well-being and health of the whole society. Therefore, the issue of quality management of medical services has been a subject of interest for many researchers for a long time. From the point of view of the article, it is therefore essential to refer to the existing state of knowledge regarding this issue by analyzing scientific publications that provide a specific picture of the state of researchers' considerations. At the same time, it should be emphasized that the large amount of literature on quality management in medical services combined with its multithreading makes it almost impossible for a single researcher to independently review it. At the same time, it is emphasized that in the context of the methodological rigor of literature research, a systematic review of the literature on the subject is becoming more and more popular (Czakon, 2015). Bearing the above in mind, the aim of this article is to present the results of a systematic analysis of the literature on the subject using bibliometric analysis of continuous scientific work on the quality management of health services in 2001-2017. The results of the above analysis were obtained from the Scopus database and technical support was provided by VOSviewer software.

\section{Research Methodology}

In order to achieve the aim of the article, a systematic review of the scientific literature, in particular scientific articles containing references to the category of medical services management and indexed by the Scopus database, was carried out. The applied research procedure is presented in Figure 1. First, the choice of the subject of research was made, i.e. a set of publications to be analyzed. This was done by pre-selecting the criteria for analysis, the time period and the document types. Then, bibliometric techniques were used to analyze the frequency of generated documents, and on this basis, time constraints were introduced and perceptual maps were analyzed in terms of the frequency and coexistence of conceptual categories. The following, fourth, stage was the analysis of the created publication clusters, and the last, fifth, an in-depth bibliometric analysis of the obtained documents and an analysis of the content of the most frequently cited scientific articles. 


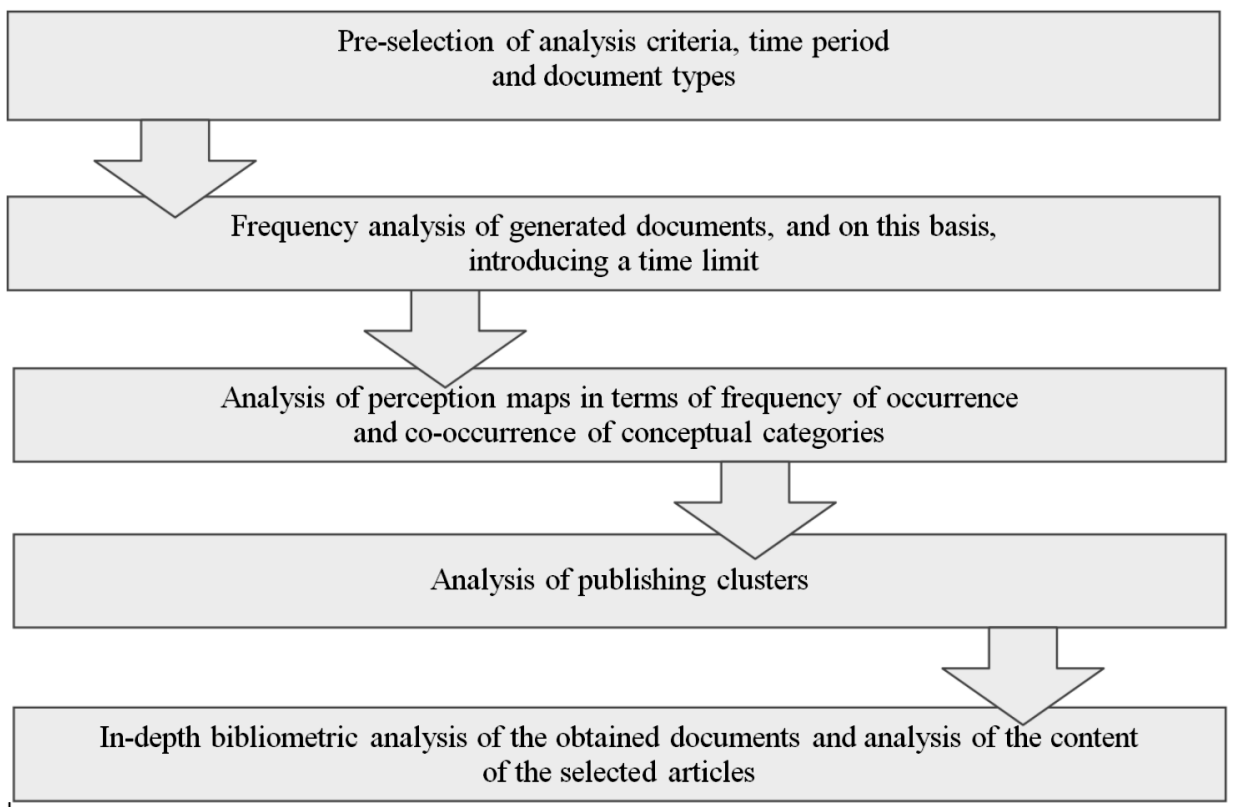

Figure 1. Stages of the research process

At the start of the analysis, two databases were used: Web of Science and Scopus. However, due to the greater number of documents available in Scopus, further analyses cover only this database. In the first step of the analysis, documents related to the concept of managing the quality of medical services were selected. The time period was initially adopted as 2001-2017, by limiting the type of documents to such forms as: article, conference paper, review, book, and book chapter published in English.

Despite the formulated restrictions, 8,170 documents were received. Therefore, in the next step, after the analysis of the time series, the time limit was again introduced, in which the criterion was the time in which the interest in the analyzed issue increased. Therefore, the period from 2011 to 2017 was adopted. The final set of criteria is presented in Figure 2.

( TITLE-ABS-KEY ( "quality management" ) AND TITLE-ABS-KEY ( "health care" OR healthcare) AND TITLE-ABS-KEY ( service) ) AND PUBYEAR > 2010 AND PUBYEAR < 2018 AND ( LIMIT-TO ( LANGUAGE , "English" ) ) AND ( LIMIT-TO ( DOCTYPE , "ar" ) OR LIMIT-TO ( DOCTYPE , "re" ) OR LIMIT-TO ( DOCTYPE, "cp" ) OR LIMIT-TO ( DOCTYPE , "ch" ) OR LIMIT-TO ( DOCTYPE , "bk") )

Figure 2. Selection criteria from the Scopus database 
As a result of applying the criteria presented in Figure 2, 5,480 publications were obtained, the summaries of which were the input data for the preparation of perception maps. These maps were used to select clusters, which made it is possible to conduct further in-depth bibliometric analysis. VOSviewer was used during map construction. The software gives the opportunity to indicate the relationships existing between multi-element data sets, by creating various forms of maps, highlighting different aspects of data presentation (Glińska \& Siemieniako, 2018; Gudanowska, 2015; Olszewska, 2017a, 2017b). In this article, the chosen form of visualization was network visualization.

\section{Trend Analysis in Scientific Publications on the Quality of Medical Services}

In accordance with the procedure described above, a fairly extensive result set was obtained at the first stage, depicted in the form of a graph shown in Figure 3.

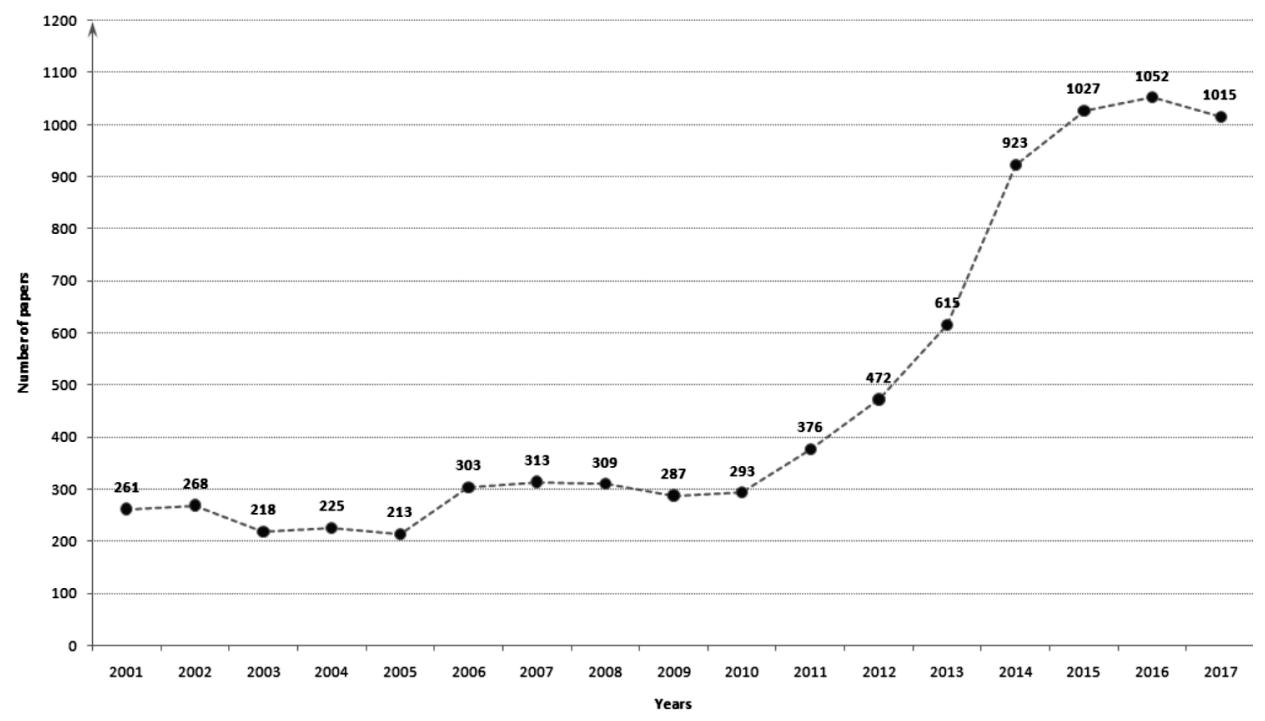

Figure 3. Changes in the number of publications in the field of quality management of medical services in the years 2001-2017 in the Scopus database

An analysis of the chart (Figure 3) indicates two stages of development of publishing interest as far as the topic of quality management of medical services is concerned. In the first stage, covering the years 2001-2010, 
there were not many clear changes in the number of publications from the studied thematic area. A larger increase, compared to the previous year, only occurred in 2006, at $48 \%$. Most probably, this was related to the introduction of the ISO standard in 2005. However, this effect was not lasting and three years later the number of publications in the field of quality management decreased again, to reach 293 in 2010. This result was close to level from the beginning of the 21st century, which gives the average annual increase in the number of publications during this period at $1.3 \%$. However, since 2010 there was a clear, sharp increase in the interest in the analyzed topic. Initially, it was an increase of $28 \%$, which gradually accelerated to reach the level of a $50 \%$ growth in 2014 . Late in the year, a sudden slowdown of changes was observed, followed by a slight decrease in 2017. However, it should be noted that in the second stage of analysis of changes in the number of publications (2010-2017), their number more than tripled, which gave an average annual increase of $13.8 \%$. For this reason, further analysis focuses only on publications issued after 2010 .

The analysis of areas of science was conducted for the data obtained in the period 2010-2017, in which issues concerning the management of the quality of medical services were discussed. The results, in the graphical form, are presented in Figure 4.

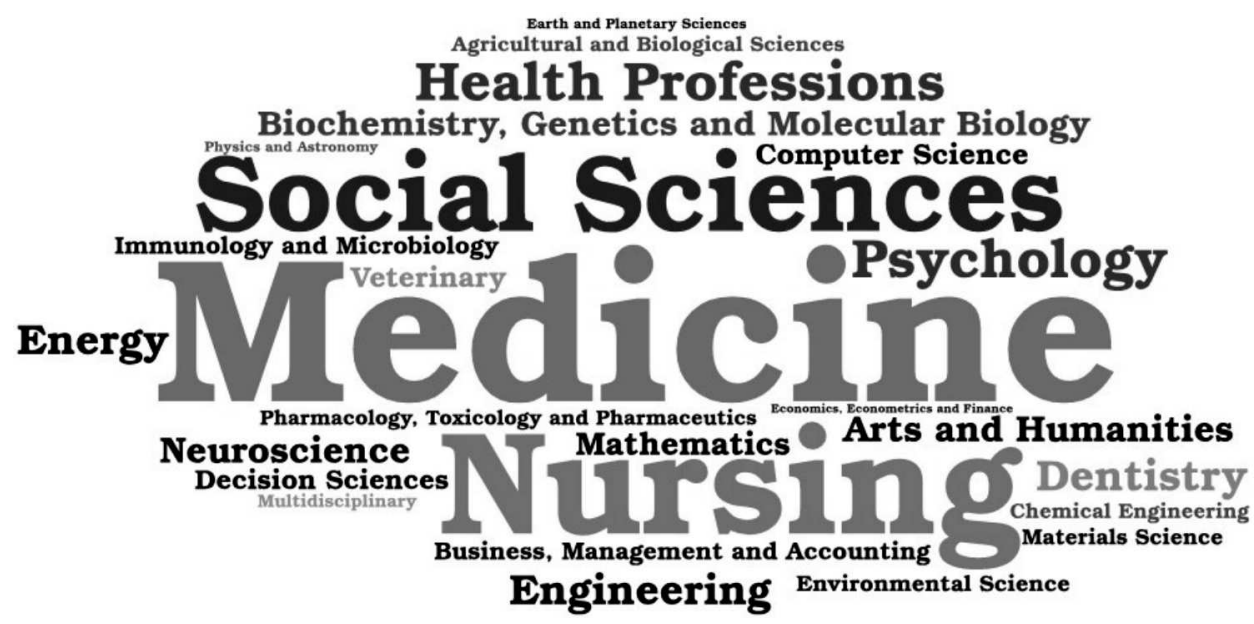

Figure 4. Scientific areas related to quality management of medical services in publications from the Scopus database in the period 2010-2017

The main areas where connections with the management of the quality of medical services were the most frequent in the analysed period were: Medicine, Nursing, Social Sciences, Biochemistry, Genetics and Molecular 
Biology, and Health Professions. Figure 4 shows how the number of publications related to the quality management of medical services in these areas was shaped, with the size of the area's name reflecting the frequency of its indication.

The analysis of the main researchers dealing with issues related to the quality management of medical services also brought interesting results (Table 1).

Table 1. List of authors of the largest numbers of publications related to the management of medical services in the Scopus database in 2011-2017

\begin{tabular}{|l|c|l|c|l|c|l|c|}
\hline \multicolumn{1}{|c|}{ Author } & $\begin{array}{c}\text { No. of } \\
\text { papers }\end{array}$ & \multicolumn{1}{|c|}{ Author } & $\begin{array}{c}\text { No. of } \\
\text { papers }\end{array}$ & \multicolumn{1}{|c|}{ Author } & $\begin{array}{c}\text { No. of } \\
\text { papers }\end{array}$ & \multicolumn{1}{|c|}{ Author } & $\begin{array}{c}\text { No. of } \\
\text { papers }\end{array}$ \\
\hline L.R. Hirschhorn & 22 & J.A. Alexander & 13 & L.V. Rubenstein & 11 & P.H. Conway & 10 \\
\hline R. Bailie & 16 & H.T. Stelfox & 13 & D.P. Scalon & 11 & M. Dixon-Woods & 10 \\
\hline G. Robert & 16 & M. McHugh & 12 & D. Bell & 10 & Y.M. Kim & 10 \\
\hline P.J. Pronovost & 14 & E.D. Peterson & 11 & Z.A. Bhutta & 10 & J.M. Pines & 10 \\
\hline
\end{tabular}

Among the 16 distinguished authors, the most frequently indicated were: L.R. Hirschhorn (22 publications), R. Bailie (16) and G. Robert (16). In turn, among the countries where researchers deal with the management of the quality of medical services, the United States holds the undisputed leading position (2734 publications), followed by (Figure 5): Great Britain (850), Canada (377) and Australia (361).

At the same time, the number of publications concerning the quality management of medical services published by scientific units/universities was surveyed (Table 2). The unquestionable leaders, similarly to the country criterion, are schools from the USA: Harvard Medical School, University of Washington, and University of Toronto (Canada).

Table 2. List of scientific units/universities issuing publications on the quality of medical services in the Scopus database in 2011-2017

\begin{tabular}{|l|c|l|c|}
\hline \multicolumn{1}{|c|}{ Affiliation } & $\begin{array}{c}\text { No. of } \\
\text { papers }\end{array}$ & \multicolumn{1}{|c|}{ Affiliation } & $\begin{array}{c}\text { No. of } \\
\text { papers }\end{array}$ \\
\hline Harvard Medical School & 205 & King's College London & 67 \\
\hline University of Toronto & 165 & Northwestern University & 66 \\
\hline University of Washington & 114 & NHS Foundation Trust & 63 \\
\hline Brigham and Women's Hospital & 97 & $\begin{array}{l}\text { David Geffen School of Medicine at } \\
\text { UCLA }\end{array}$ & 63 \\
\hline
\end{tabular}


Application of Bibliometric Analysis in the Research of Scientific...

\begin{tabular}{|l|c|l|c|}
\hline \multicolumn{1}{|c|}{ Affiliation } & $\begin{array}{c}\text { No. of } \\
\text { papers }\end{array}$ & \multicolumn{1}{|c|}{ Affiliation } & $\begin{array}{c}\text { No. of } \\
\text { papers }\end{array}$ \\
\hline University of California, San Francisco & 96 & Organisation Mondiale de la Sante & 62 \\
\hline University of California, Los Angeles & 95 & $\begin{array}{l}\text { Johns Hopkins Bloomberg School of } \\
\text { Public Health }\end{array}$ & 59 \\
\hline Massachusetts General Hospital & 87 & $\begin{array}{l}\text { Columbia University in the City of New } \\
\text { York }\end{array}$ & 58 \\
\hline $\begin{array}{l}\text { The University of North Carolina at } \\
\text { Chapel Hill }\end{array}$ & 82 & RAND Corporation & 57 \\
\hline $\begin{array}{l}\text { London School of Hygiene \& Tropical } \\
\text { Medicine }\end{array}$ & 77 & University of Calgary & 56 \\
\hline $\begin{array}{l}\text { Centers for Disease Control and } \\
\text { Prevention }\end{array}$ & 74 & University of Pennsylvania & 54 \\
\hline University of Michigan, Ann Arbor & 72 & Oregon Health and Science University & 54 \\
\hline Johns Hopkins University & 72 & University of Melbourne & 54 \\
\hline University College London & 69 & University of Oxford & 53 \\
\hline Imperial College London & 68 & Harvard School of Public Health & 52 \\
\hline The University of Sydney & 67 & $\begin{array}{l}\text { University of New South Wales UNSW } \\
\text { Australia }\end{array}$ & 51 \\
\hline
\end{tabular}

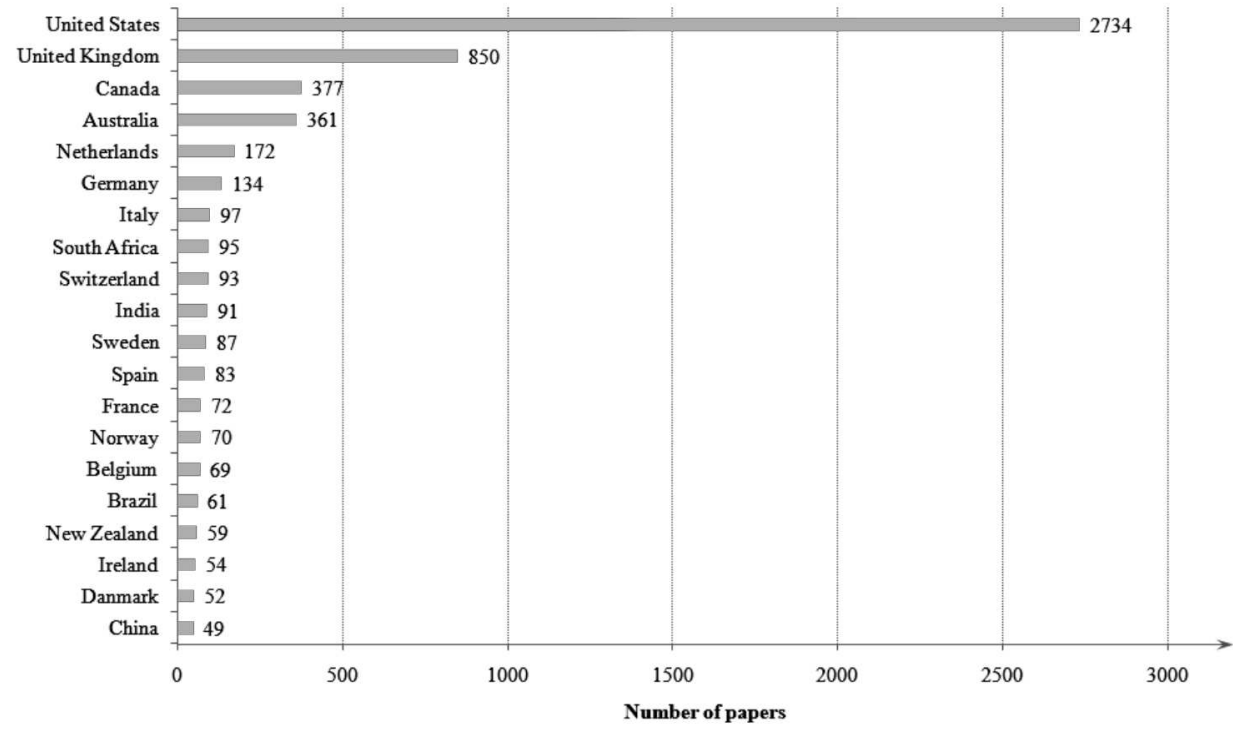

Figure 5. Number of publications on the quality management of medical services in the Scopus database in 2011-2017 by country 
Table 3. List of publications on the quality of medical services in the Scopus database in 2011-2017 with the highest numbers of citations

\begin{tabular}{|c|c|c|c|c|c|}
\hline No & Document title & Authors & Year & Source & $\begin{array}{c}\text { Cited } \\
\text { by }\end{array}$ \\
\hline 1 & $\begin{array}{l}\text { The behaviour change wheel: } \\
\text { A new method for characterising } \\
\text { and designing behaviour change } \\
\text { interventions }\end{array}$ & $\begin{array}{l}\text { S. Michie, M. M. van Stralen, } \\
\text { R. West }\end{array}$ & 2011 & $\begin{array}{l}\text { Implementation } \\
\text { Science, } \\
6(1): 42\end{array}$ & 1136 \\
\hline 2 & $\begin{array}{l}\text { Setting value-based payment } \\
\text { goals - HHS efforts to improve } \\
\text { U.S. health care }\end{array}$ & S. M. Burwell & 2015 & $\begin{array}{l}\text { New England } \\
\text { Journal of Me- } \\
\text { dicine, } 372(10) \text {, } \\
897-899\end{array}$ & 454 \\
\hline 3 & $\begin{array}{l}\text { Can available interventions end } \\
\text { preventable deaths in mothers, } \\
\text { newborn babies, and stillbirths, } \\
\text { and at what cost? }\end{array}$ & $\begin{array}{l}\text { Z. A. Bhutta, J. K. Das, } \\
\text { R. Bahl, J. E. Lawn, } \\
\text { R. A. Salam, V. K. Paul, } \\
\text { M. J. Sankar, H. Blencowe, } \\
\text { A. Rizvi, V. B. Chou, } \\
\text { N. Walker }\end{array}$ & 2014 & $\begin{array}{l}\text { The Lancet } \\
384(9940) \\
347-370\end{array}$ & 326 \\
\hline 4 & $\begin{array}{l}\text { Explaining Michigan: Developing } \\
\text { an ex post theory of a quality } \\
\text { improvement program }\end{array}$ & $\begin{array}{l}\text { M. Dixon-Woods, C. L. Bosk, } \\
\text { E. L. Aveling, C. A. Goeschel, } \\
\text { P. J. Pronovost }\end{array}$ & 2011 & $\begin{array}{l}\text { Milbank } \\
\text { Quarterly } \\
89(2), 167-205\end{array}$ & 285 \\
\hline 5 & $\begin{array}{l}\text { Part 1: Executive summary: } \\
2015 \text { American Heart Associa- } \\
\text { tion guidelines update for car- } \\
\text { diopulmonary resuscitation and } \\
\text { emergency cardiovascular care }\end{array}$ & $\begin{array}{l}\text { R. W. Neumar, M. Shuster, } \\
\text { C. W. Callaway, L. M. Gent, } \\
\text { D. L. Atkins, F. Bhanji, } \\
\text { S. C. Brooks, A. R. De Caen, } \\
\text { M. W. Donnino, J. M. E. Fer- } \\
\text { rer, M. E. Kleinman, S. L. Kro- } \\
\text { nick, E. J. Lavonas, M. S. Link, } \\
\text { M. E. Mancini, L. J. Morrison, } \\
\text { R. E. O'Connor, R. A. Sam- } \\
\text { son, S. M. Schexnayder, } \\
\text { E. M. Singletary, E. H. Sinz, } \\
\text { A. H. Travers, M. H. Wyckoff, } \\
\text { M. F. Hazinski }\end{array}$ & 2015 & $\begin{array}{l}\text { Circulation } \\
132(18) \\
315-367\end{array}$ & 217 \\
\hline
\end{tabular}

The next step in the research process was to perform a citation analysis (Table 3). It is worth emphasizing that the importance of the analysis of citations results from its focus on the importance of a single publication for the discipline. At the same time, such an analysis allows us to assess the range of impact of the results (Czakon, 2015). Five articles were selected from the Scopus database, which are particularly often cited by researchers who deal with the issue of managing the quality of medical services. The first place among the most-cited items (1136 citations in the Scopus database) is held by an article titled: The behaviour change wheel: A new method for characterising and designing behaviour change interventions by S. Michie, M. M. van Stralen, R. West (Michie et al., 2011). Second was the publication entitled Setting value-based payment goals - HHS efforts to improve U.S. health care by S. M. Burwell (454 citations) (Burwell, 2015). Third 
(326 citations) was: Can available interventions end preventable deaths in mothers, newborn babies, and stillbirths, and at what cost? by Z. A. Bhutta, J. K. Das, R. Bahl, J. E. Lawn, R. A. Salam, V. K. Paul, M. J. Sankar, H. Blencowe, A. Rizvi, V. B. Chou, N. Walker (Bhutta et al., 2014), followed by (285 citations) Explaining Michigan: Developing an Ex post theory of a quality improvement program (Dixon-Woods et al., 2011). Fifth (217 citations) was Part 1: Executive summary: 2015 American Heart Association guidelines update for cardiopulmonary resuscitation and emergency cardiovascular care (Neumar et al., 2015).

\section{Analysis and Assessment of Perception Maps}

On the basis of the data obtained from Scopus related to publications on the quality of medical services, perception maps were developed using VOSviewer software. When preparing maps, concepts that were selected in the key criterion and those that do not form the basis of the analysis were excluded as they relate to, for example, the region (such as Europe, USA, India) or typical research activities (e.g. survey, questionnaire). The obtained results are presented in the form of a map in Figure 6.

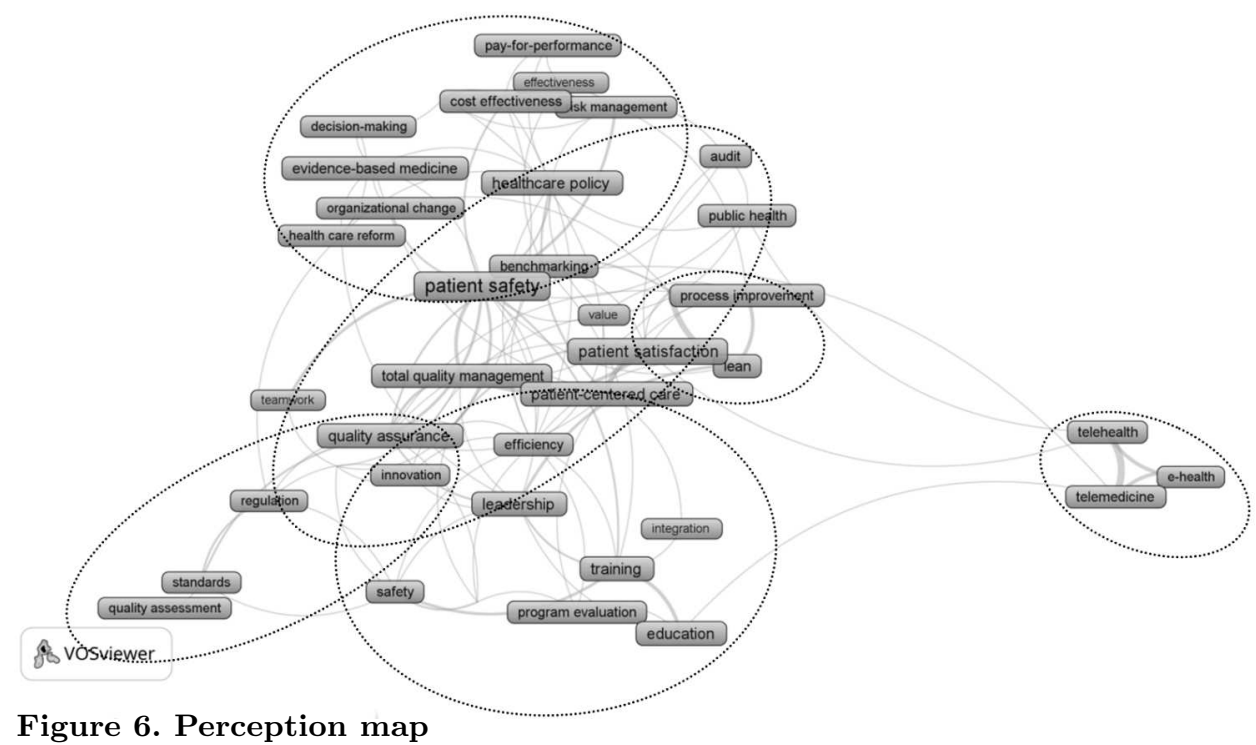

The analysis of Figure 6 indicates the existence of six clusters of terms related to the management of the quality of medical services. Details of the obtained clusters are presented in Table 4. 
Joanna Anna Jończyk, Anna Małgorzata Olszewska, Kamila Jończyk

Table 4. Clusters identified through the analysis

\begin{tabular}{|c|c|c|c|c|c|}
\hline Keyword & Occurrences & Co-occurrence & Keyword & Occurrences & Co-occurrence \\
\hline \multicolumn{3}{|c|}{ Cluster 1} & \multicolumn{3}{|c|}{ Cluster 3} \\
\hline benchmarking & 22 & 6 & education & 41 & 7 \\
\hline cost effectiveness & 24 & 9 & efficiency & 21 & 12 \\
\hline decision-making & 12 & 3 & $\begin{array}{l}\text { health information } \\
\text { technology }\end{array}$ & 19 & 6 \\
\hline effectiveness & 10 & 4 & integration & 10 & 2 \\
\hline $\begin{array}{l}\text { evidence-based } \\
\text { medicine }\end{array}$ & 39 & 6 & leadership & 43 & 13 \\
\hline health care reform & 18 & 6 & patient-centered care & 48 & 14 \\
\hline healthcare policy & 41 & 11 & program evaluation & 21 & 4 \\
\hline organizational change & 19 & 5 & safety & 20 & 10 \\
\hline pay-for-performance & 23 & 3 & training & 45 & 14 \\
\hline prevention & 15 & 5 & \multicolumn{3}{|c|}{ Cluster 4} \\
\hline risk management & 12 & 9 & quality assessment & 16 & 1 \\
\hline \multicolumn{3}{|c|}{ Cluster 2} & quality assurance & 53 & 18 \\
\hline audit & 23 & 4 & regulation & 14 & 6 \\
\hline communication & 29 & 10 & standards & 15 & 6 \\
\hline innovation & 18 & 5 & \multicolumn{3}{|c|}{ Cluster 5} \\
\hline organizational culture & 11 & 5 & lean & 35 & 16 \\
\hline patient safety & 122 & 34 & process improvement & 24 & 9 \\
\hline patient satisfaction & 56 & 18 & six sigma & 17 & 14 \\
\hline public health & 28 & 5 & \multicolumn{3}{|c|}{ Cluster 6} \\
\hline teamwork & 11 & 4 & e-health & 18 & 8 \\
\hline $\begin{array}{l}\text { total quality } \\
\text { management }\end{array}$ & 34 & 14 & telehealth & 23 & 15 \\
\hline value & 10 & 6 & telemedicine & 25 & 15 \\
\hline
\end{tabular}

Thus, the first cluster included issues related to relationships in the management of the quality of medical services with the broadly understood changes in healthcare organizations. The second cluster is related to internal quality management factors in healthcare organizations. The third cluster is the issue of development and education, while the fourth describes the formal issues related to quality management in the area of regulation and standardization. The fifth cluster refers to the subject of management con- 
Application of Bibliometric Analysis in the Research of Scientific...

cepts related to quality improvement in organizations (i.e. concepts such as lean, process improvement, six sigma), while the last cluster includes technological aspects of quality management in medical service.

\section{In-Depth Bibliometric Analysis of Basic Trends and Categories Related to the Quality of Medical Services}

In order to conduct an in-depth bibliometric analysis of issues related to the quality of medical services, one of the clusters was chosen, i.e. cluster no. 5, which included issues such as Lean, Process improvement or Six sigma. The technique of basic content analysis was applied here, using the findings contained in six publications concerning the examined categories, whose number of citations was greater than 50. Figure 7 presents the selection criteria for cluster 5 from the Scopus database (limitation to Lean and Six sigma).

( TITLE-ABS-KEY ( "quality management" ) AND TITLE-ABS-KEY ( "health care" OR healthcare) AND TITLE-ABS-KEY ( service ) AND TITLE-ABSKEY ( lean OR "six sigma" OR "process improvement" ) ) AND TITLE-ABSKEY ( service ) ) AND PUBYEAR > 2010 AND PUBYEAR < 2018 AND ( LIMITTO ( LANGUAGE , "English" ) ) AND ( LIMIT-TO ( DOCTYPE , "ar" ) OR LIMIT-TO ( DOCTYPE, "re" ) OR LIMIT-TO ( DOCTYPE, "cp" ) OR LIMIT-TO ( DOCTYPE , "ch" ) OR LIMIT-TO ( DOCTYPE , "bk" ) )

Figure 7. Selection criteria for cluster 5 from the Scopus database

A description of selected publications containing the author, title, year of citation, description of the study, and its results is presented in Table 5 .

In the context of the data presented above, it is worth pointing out that the broadly understood content analysis, understood as systematic software perception of messages, is an indispensable element of most research. Regardless of the studied problem or even the chosen method, the researcher always has to face a ready material that requires analysis. The procedure in question uses content analysis based on the findings made after perusing 6 abstracts of the most cited articles listed in Table 5. The main purpose of the publication, its context, the data quality, and the possibility of generalizing the results were considered.

The main purpose of the publication, the applied methodology and the results of the research were considered. The purpose of the article entitled Lean in healthcare: A comprehensive review (D'Andreamatteo et al., 2015) 
Table 5. List of publications on the quality of cluster 5 medical services in the Scopus database in 2011-2017

\begin{tabular}{|c|c|c|c|c|c|}
\hline No & Document title & Authors & Year & Source & $\begin{array}{c}\text { Cited } \\
\text { by }\end{array}$ \\
\hline 1 & $\begin{array}{l}\text { Lean in healthcare: A compre- } \\
\text { hensive review }\end{array}$ & $\begin{array}{l}\text { A. D'Andreamatteo, L. Ianni, } \\
\text { F. Lega, M. Sargiacomo }\end{array}$ & 2015 & $\begin{array}{l}\text { Health Policy, } \\
119,1197-1209\end{array}$ & 70 \\
\hline 2 & $\begin{array}{l}\text { Quality initiatives: Lean ap- } \\
\text { proach to improving perfor- } \\
\text { mance and efficiency in a radi- } \\
\text { ology department }\end{array}$ & $\begin{array}{l}\text { J. B. Kruskal, A. Reedy, L. Pas- } \\
\text { cal, M. P. Rosen, P. M. Boiselle }\end{array}$ & 2012 & $\begin{array}{l}\text { RadioGraphics, } \\
32(2), 573-587\end{array}$ & 67 \\
\hline 3 & $\begin{array}{l}\text { Lean Management in Academic } \\
\text { Surgery }\end{array}$ & $\begin{array}{l}\text { R. M. Collar, A. G. Shu- } \\
\text { man, S. Feiner, A. K. Mc- } \\
\text { Gonegal, N. Heidel, M. Duck, } \\
\text { S. A. McLean, J. E. Billi, } \\
\text { D. W. Healy, C. R. Bradford }\end{array}$ & 2012 & $\begin{array}{l}\text { Journal of the } \\
\text { American Col- } \\
\text { lege of Sur- } \\
\text { geons, } 214(6) \\
928-936\end{array}$ & 65 \\
\hline 4 & Evaluating Lean in healthcare & N. Burgess, Z. Radnor & 2013 & $\begin{array}{l}\text { International } \\
\text { Journal of } \\
\text { Health Care } \\
\text { Quality As- } \\
\text { surance, 26(3), } \\
220-235\end{array}$ & 61 \\
\hline 5 & $\begin{array}{l}\text { Improving The Quality Of } \\
\text { Health Care: What's Taking So } \\
\text { Long? }\end{array}$ & M. R. Chassin & 2013 & $\begin{array}{l}\text { Health Af- } \\
\text { fairs, 32(10), } \\
\text { pp. 1761-1765 }\end{array}$ & 55 \\
\hline 6 & $\begin{array}{l}\text { How does lean work in emer- } \\
\text { gency care? A case study of } \\
\text { a lean-inspired intervention at } \\
\text { the Astrid Lindgren Children's } \\
\text { hospital, Stockholm, Sweden }\end{array}$ & $\begin{array}{l}\text { P. Mazzocato, R. J. Holden, } \\
\text { M. Brommels, H. Aronsson, } \\
\text { U. Bäckman, M. Elg, J. Thor }\end{array}$ & 2012 & $\begin{array}{l}\text { BMC Health } \\
\text { Services } \\
\text { Research, } \\
12(1): 28\end{array}$ & 52 \\
\hline
\end{tabular}

was to conduct a comprehensive review of the main issues concerning the implementation of Lean in healthcare. Therefore, scientific papers published before September 2013 were identified. After analyzing 243 articles on Lean, a thesis was put forward that this method is promising for hospitals as far as increasing their productivity is concerned. The authors emphasize USA's role as the leading country in terms of the application of this method. At the same time, they also indicate the published work focused mainly on barriers, challenges and success factors of Lean, while pointing to the lack of an appropriate framework and critical assessment of this method in the context of the entire hospital management system. At the same time, researchers urge the environment to further explore this method, primarily due to the huge amount of investment required and the involvement of the entire organization in its implementation.

The second of the researched publications entitled Quality initiatives: Lean approach to improving performance and efficiency in a radiology de- 
partment, concerned the practical aspects of Lean implementation in radiology departments in hospitals (Kruskal et al., 2012). Positive results of this approach were pointed out, especially for those radiology departments whose efficient functioning relies on smooth patient flow and uninterrupted operation of equipment. At the same time, the authors stress that the use of Lean methods in isolation from other organizational problems is unlikely to improve the overall performance in the context of a permanent improvement of functioning. Therefore, they propose a gradual but continuous and comprehensive "slim transformation" of work and work culture philosophy, based on equal commitment and equal respect for all staff members, waste elimination, standardization of work processes, improvement of flow in all processes, the use of visual communication and information, data collection, as well as change implementation and management.

The third publication, entitled Lean Management in Academic Surgery, shows Lean as a management system designed to increase productivity by eliminating waste in surgical wards (Collar et al., 2012). The publication presents a quasi-experimental study involving the implementation of lean thinking by a multidisciplinary task force in the operating room of the hospital's otolaryngology department. The aim of the experiment was to determine whether systematic implementation of lean thinking in the academic otolaryngology operating theater improves efficiency and profitability and maintains team morale and educational opportunities. The results of the study confirmed the adopted theses that the use of Lean Management techniques for a single operating room and surgical services improved the efficiency of the operating room and staff morale.

An article on Evaluating Lean in healthcare (Burgess \& Radnor, 2013), the aim of which was to present the results of Lean implementation in English hospitals, is an empirical analysis of all annual reports and websites of English hospitals providing a thorough analysis of the status of Lean in English healthcare. The authors point to frequently isolated and non-systemic Lean implementation, which is less effective in practice. At the same time, the authors emphasize that the right direction is a more systematic approach to the implementation of this method in public hospitals.

The goals of the next (fifth) article entitled Improving The Quality Of Health Care: What's Taking So Long? (Chassin, 2013) is a summary of the reports of the American Institute of Medicine regarding the need to improve the quality of medical services in the context of patient safety. The authors point out that newer, more effective strategies and tools are needed, such as Lean or Six Sigma, to meet the complex qualitative challenges faced by health care. At the same time, they point to the persistence 
of changes in the organizational culture of most American hospitals towards creating a culture of security and responsibility for adhering to safe practices.

The last of the articles, entitled How does lean work in emergency care? Astrid Lindgren Children's hospital, Stockholm, Sweden (Mazzocato et al., 2012) deals with the use of lean thinking in Swedish healthcare. The article presents a detailed case study analyzing an intervention inspired by the lean technique in the Swedish emergency department for pediatric patients. The authors, based on the theoretical propositions of Spear and Bowen, showed how Lean changes translated into better management of the pediatric care process. The benefits included improved waiting time (19-24\%), positive changes among staff regarding work scheduling, communication, coordination, specialist knowledge, workspace layout and problem solving.

Summing up the aspect of content analysis by means of the presented findings, it clearly helps to clarify both the scope and the desirable directions of further investigations in the studied areas (i.e. Lean Management). The results presented above undoubtedly serves as a proof of the positive impact of its use as a complement to bibliometric analysis. In the proposed sample of content analysis, the authors focused both on what and how the LM was described in the empirical material, placing a particular emphasis on capturing the diversity of the described problem. It can be assumed that these operations provide a more comprehensive insight into the studied issues by highlighting the possibility of increasing the intersubjectivity of the analyzes carried out.

\section{Conclusions}

Summarizing the above considerations, it should be stated, first of all, that issues concerning the quality management of medical services remain very popular among researchers, which is confirmed by the significant increase in publications in the years 2001-2017. At the same time, with such a significant global output, it is difficult to imagine the study of literature on the subject without the use of appropriate techniques dedicated to analyzing the collected data contained in the available bibliographic databases, especially that these databases are becoming more and more extensive sources of information. This fact, on the one hand, is a great challenge for scholars, while on the other, it can pose serious difficulties in working for a single person seeking the truth about the examined reality. At the same time, it 
is worth emphasizing that bibliometric techniques are used to analyze the entire population in terms of selected features. Those most frequently used are analysis of the number of publications and analysis of the number of citations that allow to assess the size of the set and its meaning.

It also should be emphasized that literature review cannot be based solely on numerical analysis. It is also important to conduct content analysis, which allows the identification of the publications that present a point of view that is particularly useful for the researcher, as far as his/her goal and focus on the findings to be made there are concerned. Therefore, this paper uses bibliomentric analysis, which allowed to systematize significant amounts of the collected material regarding the categories of quality management of medical services. The study used the Scopus database and, after applying time criteria (2011-2017) and limiting the type of documents to such forms as article, conference paper, review, book and book chapter published in English, 5,480 positions were eventually accepted for the analysis.

The persistently high number of publications annually (especially in the last 4 years) regarding the management of the quality of medical services shows a constant interest in the topic. The number of the most cited publications, based on the Scopus database, an analysis of links between categories of the quality of medical services with other categories (identification of 6 clusters) not only shows intensive development of quality management of medical services, but also sets directions of development and perspectives for changes in healthcare organizations around the world. Development of the quality of medical services in the context of conceptual categories such as Lean, Process improvement or Six sigma was considered particularly interesting and may help other researchers in performing an in-depth analysis of the subject. Lastly, it is worth emphasizing that the applied bibliometric analysis is not free of limitations, e.g. resulting from the very nature of bibliometric research or from using a single database to select publications. However, it should be noted that the analysis and its results can be a starting point not only for researchers interested in the quality management in medical services but also for other researchers involved in systematic review of literature in other fields.

\section{Acknowledgements}

This article is based on J. Jończyk's research funded by the National Science Center (No. DEC-2011/03/B/HS4/04544) and A. Olszewska's research financed by Ministry of Science and Higher Education (S/WZ/1/2017). 


\section{R E F E R E N C E S}

Bhutta, Z. A., Das, J. K., Bahl, R., Lawn, J. E., Salam, R. A., Paul, V. K., Sankar, M. J., et al. (2014). Can available interventions end preventable deaths in mothers, newborn babies, and stillbirths, and at what cost? The Lancet, 384(9940), 347-370.

Burgess, N., \& Radnor, Z. (2013). Evaluating Lean in healthcare. International Journal of Health Care Quality Assurance, 26(3), 220-235.

Burwell, S. M. (2015). Setting value-based payment goals - HHS efforts to improve U.S. health care. New England Journal of Medicine, 372(10), 897-899.

Chassin, M. R. (2013). Improving The Quality Of Health Care: What's Taking So Long? Health Affairs, 32(10), 1761-1765.

Collar, R. M., Shuman, A. G., Feiner, S., McGonegal, A. K., Heidel, N., Duck, M., McLean, S. A., et al. (2012). Lean Management in Academic Surgery. Journal of the American College of Surgeons, 214(6), 928-936.

Czakon, W. (2015). Podstawy metodologii badań w naukach o zarzadzaniu. Oficyna Wolter Kluwers.

D'Andreamatteo, A., Ianni, L., Lega, F., \& Sargiacomo, M. (2015). Lean in healthcare: A comprehensive review. Health Policy, 119, 1197-1209.

Dixon-Woods, M., Bosk, C. L., Aveling, E. L., Goeschel, C. A., \& Pronovost, P. J. (2011). Explaining Michigan: Developing an ex post theory of a quality improvement program. Milbank Quarterly, 89(2), 167-205.

Glińska, E., \& Siemieniako, D. (2018). Binge drinking in relation to services - bibliometric analysis of scientific research directions. Engineering Management in Production and Services, 10(1), 45-54.

Gudanowska, A. E. (2015). Tworzenie mapy wiedzy opartej na tematyce projektów badawczo-rozwojowych na przykładzie województwa podlaskiego [Creating knowledge maps based on the themes of $\mathrm{R} \& \mathrm{D}$ projects on the example of the Podlaskie region]. Economics and Management, r(1), 257-270.

Kruskal, J. B., Reedy, A., Pascal, L., Rosen, M. P., \& Boiselle, P. M. (2012). Quality initiatives: Lean approach to improving performance and efficiency in a radiology department. RadioGraphics, 32(2), 573-587.

Mazzocato, P., Holden, R. J., Brommels, M., Aronsson, H., Bäckman, U., Elg, M., \& Thor, J. (2012). How does lean work in emergency care? A case study of a lean-inspired intervention at the Astrid Lindgren Children's hospital, Stockholm, Sweden. BMC Health Services Research, 12(1): 28.

Michie, S., van Stralen, M. M., \& West, R. (2011). The behaviour change wheel: A new method for characterising and designing behaviour change interventions. Implementation Science, 6(1): 42.

Neumar, R. W., Shuster, M., Callaway, C. W., Gent, L. M., Atkins, D. L., Bhanji, F., Brooks, S. C., et al. (2015). Part 1: Executive summary: 2015 American Heart Association guidelines update for cardiopulmonary resuscitation and emergency cardiovascular care. Circulation, 132(18), 315-367. 
Application of Bibliometric Analysis in the Research of Scientific...

Olszewska, A. M. (2017a). Analysis of changes in perception of organizations quality maturity. 8th International Conference on Engineering, Project, and Product Management (EPPM 2017), 189-197.

Olszewska, A. M. (2017b). Research issues undertaken within quality management the owerview od selected literature. Engineering Management in Production and Services, 9(1), 74-83. 